\title{
矩形断面蛇行開水路流れの 三次元乱流構造に関する研究
}

\author{
杉山 均 ${ }^{1} \cdot$ 秋山光庸 ${ }^{2} \cdot$ 佐藤亮輔 ${ }^{3}$ \\ ${ }^{1}$ 正員 工博 宇都宮大学助教授 大学院工学研究科 ( $\bar{T} 321-8585$ 宇都宮市陽東 7-1-2) \\ ${ }^{2}$ Ph.D. 宇都宮大学教授 大学院工学研究科 ( $7321-8585$ 宇都宮市陽東 7-1-2) \\ 3 宇都宮大学大学院 エネルギー環境科学専攻 (F 321-8585 宇都宮市陽東 7-1-2)
}

\begin{abstract}
蛇行開水路流れでは流れの発達に伴って方向の異なる遠心力が作用し，かつ自由水面の存在によりその流動挙 動, 乱流構造は複雑に変化する. 本研究では 1 周期長さの矩形断面蛇行開水路流れを対象に代数応力モデルを 用いて解析し，蛇行開水路流れの三次元流動挙動および解析手法の有用性について検討を加えた. 計算結果に は非定常性が認められた。このため，解析結果を時間平均することにより実験結果と比較した．その結果，本 解析手法は蛇行開水路流れ場における主流方向速度の流れ方向への变化やレイノルズ応力の特徴的分布を比較 的良好に再現した。 また，本解析の蛇行開水路流れに生成される断面内の二次流れも非定常性を示し，そのパ ターンは複雑に変化することを明らかにした.
\end{abstract}

Key Words : numerical analysis, turbulent flow, meandering open-channel, secondary flow, Reynolds stress model, boundary-fitted coordinate system

\section{1. 緒 言}

いくつかの曲がり形状より構成される蛇行開水 路流れは, 多くの自然河川に見られる典型的な流れ 場である。しかし，曲がりによる遠心力，断面内の 圧力勾配変化, 自由水面の存在による乱流構造の変 化が互いに干渉し合いながら流れ場を形成してい くためその流動挙動は複雑である。こうした流れは 河道の洗掘, 土砂の堆積, 河川水位変化などと言っ た現象とも梁く関わり合う。同時に, 護岸工事など 実際問題とも関連し, 河川工学上で重要な流れ場で ある。

こうした蛇行開水路に関する研究は, 複断面開水 路を含めた多くの直線開水路に関する研究（例えば 文献1),2)など）と比較すると少ない。この種の蛇行 開水路に関する実験として古くは Toebes・Sooky ${ }^{3)}$ の研究があげられる。彼らは矩形断面を有する単断 面, 複断面蛇行開水路流れを対象にプラントル型ピ トー管を用いて平均速度場を測定することより流 動損失, 複断面開水路における高水敷流路流れと低 水路流れとの干涉問題などを報告した。その結果， 流動損失は同一の流量, 径深, 流路幅を持つ直線開 水路と比較して, 蛇行開水路は単位長さあたり 2.5 倍ほど大きいこと, 単断面蛇行開水路の二次流れと 複断面開水路のそれとは大きく異なることを報告し
ている. Kiely ${ }^{4)}$ はレーザ・ドップラー流速計を用い て矩形断面を有する複断面蛇行開水路内の測定を行 い, 平均速度や水位変化について調べている。低水 路に扔ける二次流れは上流から下流を見た断面で反 時計方向に循環し, 主流方向速度の $30 \%$ 程度の速 度を有することを報告している．単断面の蛇行開水 路の実験的研究に関して,玉井・池内・山崎( $)^{2}$ は反 転する $90^{\circ}$ 曲がり流路を直線流路で繋いだ蛇行開 水路を対象に二次流れを含む平均速度成分と水面形 状分布の計測結果を報告している。さらに, 池田 田中.千代田6) ${ }^{6}$ 蛇行管路を対象としてレイノルズ 応力, 乱流エネルギー分布の測定結果を報告してい る.同時に,こうした乱流特性量と平均速度場との 相関についても言及している。渡辺・大成・斉藤7) は低レイノルズ数流れ場における蛇行開水路内の組 織構造について解析し, 蛇行開水路には, 蛇行低速 領域，大規模凸岸渦，水平渦および大規模縦渦の 4 つの組織構造が形成されることを報告している.

こうした蛇行開水路の実験解析の状況にあって, その乱流構造ならびに特異なふるまいをするであろ う二次流れ分布をレーザ・ドップラー流速計を用い て詳細に測定した結果が Shiono・Muto ${ }^{8)}$, 武藤・塩 野·今本・石垣 ${ }^{9)} よ り$ 最近報告された. Shiono らは台 形断面を有する蛇行開水路流れ, 武藤らは矩形断面 
を有する蛇行開水路流れを対象にレイノルズ応力 成分を含む詳細な乱流計測結果を提示している。 彼らは最大主流方向速度は曲がり内壁に存在する など蛇行開水路に特徵的な現象を実験により明ら かにしている．同時に乱流モデルの普遍性向上を 図る上から，こうした複雑乱流場の基礎的な実験 データが不可欠であることも言及している.

以上の実験解析に対して, 理論的解析例も報告さ れている. 池内.玉井10)は水深方向に積分し, 平均 化された運動方程式を摂動法の 2 次項まで考慮する ことにより解析解を得た。解析解は平均速度, 水位 分布を比較的良好に予測できることを報告してい る. 彼らの解析解が二次元であるのに対し, 池谷・ 玉井 ${ }^{11)}$ はレイノルズ応力もモデル化し三次元蛇行 開水路を対象に数值解析結果を報告しているが, 主 流方向速度および二次流れ分布を十分再現している とは言い難い，以上に示すように，蛇行開水路流れ に関する数值予測はいくつか報告されているが,レ イノルズ応力分布の予測までも含め数値解析した研 究はその形状, 乱流構造の複雑さゆえ未だ報告され ていない。

そこでこれまでの研究経緯を考虑し, 本研究では 蛇行開水路流れを対象に数值解析を試み, 本解析手 法の妥当性を検討するとともに,この種の流れの流 動挙動について新たな知見を得ることを目的とす る. 計算対象としてはレイノルズ応力までも詳細に 測定した武藤・塩野·今本・石垣 ${ }^{9}$ の実験を対象とす る. 彼らは単断面, 複断面の蛇行開水路流れの計測 結果を示しているが, 本研究では単断面蛇行開水路 流れを対象とした. 本解析流れの場合, 乱れの非等 方性は顕著に現れるものと予測されるが,こうした 非等方性を再現するため代数応力モデルを用いた。 さらに蛇行形状に沿った境界条件も正確に設定する ことが必要であり,この点に関しては境界適合座標 系を導入し解析を行った。

\section{2. 記号}

$$
\begin{aligned}
k & : \text { 乱流エネルギー } \\
P & : \text { 圧力 } \\
R & : \text { 径深 } \\
R_{e} & : \text { レイノルズ数 }=4 R U_{b} / \nu \\
r & : \text { 曲がり半径 } \\
r_{c} & : \text { 曲り流路中心位置までの半径 } \\
T^{*} & : \text { 無次元時間 }=t U_{b} / 4 R \\
t & : \text { 時間 } \\
\overline{u_{i} u_{j}} & : \text { レイノルズ応力 }
\end{aligned}
$$

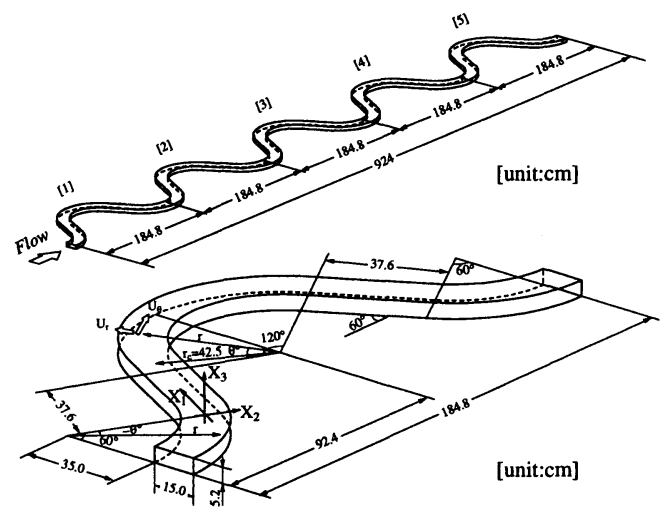

Fig.1 Meandering channel and definition of coordinate system

$U_{i}$ : 直交直線座標系での $i$ 方向平均速度

$U_{b}$ : 断面内主流方向平均速度

$U_{r}$ : 円筒座標上の半径方向平均速度

$U_{\theta}$ : 円筒座標上の円周方向平均速度

$\overline{U_{*}}$ : 平均摩擦速度

$u_{r}$ : 円筒座標上の半径方向変動速度

$u_{\theta}$ : 円筒座標上の円周方向変動速度

$u_{z}$ : 円筒座標上の深さ方向変動速度

$X_{i}$ : 直交直線座標系での $i$ 方向座標軸

$z:$ 円筒座標上の奥行き方向座標

$\delta_{i j}:$ クロネッカーのデルタ記号

$\theta:$ 曲がり角度

$\epsilon:$ 乱流エネルギー散逸率

$\nu:$ 分子粘性係数

$\nu_{t}:$ 渦動粘性係数 $=c_{\mu} k^{2} / \epsilon$

$\rho:$ 密度

$\omega_{\theta}:$ 主流方向渦度

$\omega_{b}^{2}:$ 主流方向渦度の断面内二乗平均値

(一):アンサンブル平均

\section{3. 解析手法}

\section{(1) 計算対象実験}

本解析においては, 武藤ら9)の示した矩形断面を 有する単断面蛇行開水路を計算対象とした. 実験装 置概略図, 計算座標系を Fig.1に示す. 蛇行開水路 は図に示すように 5 周期の蛇行水路より構成され， その一周期長さは $184.8 \mathrm{~cm}$ でその全長は $924 \mathrm{~cm}$ であ る. さらにその半周期蛇行部は曲がり角 $60^{\circ}$, 曲が り半径 $r_{c}=42.5 \mathrm{~cm}$ の曲がり部と $37.6 \mathrm{~cm}$ の直線部 
より構成されている。この時蛇行状況を分類する パラメータの蛇行度 (蛇行水路実長/蛇行波長) は 1.37 である。開水路断面は矩形断面形状を有し， その河床幅は $15.0 \mathrm{~cm}$ である. 平均水深は $5.2 \mathrm{~cm}$ と 報告されている。測定領域は入口から 4 番目の上 流側半周期の蛇行部であり,この位置は蛇行開水 路出口から $2 \mathrm{~m}$ 以上離れ下流部の影響はないこと が報告されている。測定に際しては二成分レーザ、 ドップラー流速計を用い蛇行開水路の 7 断面にて 時間平均速度, レイノルズ応力分布の詳細な計測 を行っている。レイノルズ数は代表速度に断面内 主流方向平均速度, 代表寸法に径深 R の 4 倍を 取った值で $R_{e}=2.19 \times 10^{4}$ である.

座標系に関しては図に示すように直線開水路では 直交直線座標系を蛇行開水路では円筒座標系を用い 各特性量を示した. 直交座標系は主流方向を $X_{1}$, 断 面方向を $X_{2}, X_{3}$ とし直線開水路の入口断面の河床 中央点を便宜的に原点とした。 また直線開水路を挟 んで上流部, 下流部に位置する曲がり部の各断面を 示す際には, それぞれ曲がり角 $\theta$ の正符号, 負符号 をもって定義した. 従って半周期蛇行開水路の入口 は $\theta=-60^{\circ}$, 出口断面は $\theta=60^{\circ}$ に相当する.

\section{(2) 支配方程式}

運動方程式は以下の様に示される。

$$
\frac{D \overline{U_{i}}}{D t}=-\frac{1}{\rho} \frac{\partial \bar{P}}{\partial X_{i}}+\frac{\partial}{\partial X_{j}}\left(\nu \frac{\partial \overline{U_{i}}}{\partial X_{j}}-\overline{u_{i} u_{j}}\right)
$$

ここで $D / D t=\partial / \partial t+\overline{U_{j}} \partial / \partial X_{j}$ である.上式中のレ イノルズ応力を求める際には以下に示すレイノルズ 応力輸送方程式を解くものとした.

$$
\begin{aligned}
& \frac{D \overline{u_{i} u_{j}}}{D t}=-\left(\overline{u_{i} u_{k}} \frac{\partial U_{j}}{\partial X_{k}}+\overline{u_{j} u_{k}} \frac{\partial U_{i}}{\partial X_{k}}\right) \\
& -\frac{\partial}{\partial X_{k}}\left[\left(\overline{u_{i} u_{j} u_{k}}-\nu \frac{\partial \overline{u_{i} u_{j}}}{\partial X_{k}}+\frac{\bar{p}}{\rho}\left(\delta_{j k} u_{i}+\delta_{i k} u_{j}\right)\right]\right. \\
& +\overline{\frac{p}{\rho}\left(\frac{\partial u_{i}}{\partial X_{j}}+\frac{\partial u_{j}}{\partial X_{i}}\right)}-2 \nu \overline{\frac{\partial u_{i}}{\partial X_{k}} \frac{\partial u_{j}}{\partial X_{k}}}
\end{aligned}
$$

しかし上式を直接的に解くことは不可能でありい くつかのモデル化が必要となる. 左辺第 1 項の対流 項，ならびに右辺第 2 項に対しては Rodi ${ }^{12}$ 近似を 用いてモデル化を行った。この近似より対流, 拡散 項は以下の式に示すように微分型から代数式に変換 される。

$$
\begin{array}{r}
\frac{D \overline{u_{i} u_{j}}}{D t}-D i f f_{i j}=\frac{\overline{u_{i} u_{j}}}{k}\left(P_{k}-\epsilon\right) \\
P_{k}=-\overline{u_{k} u_{l}} \frac{\partial \overline{U_{k}}}{\partial X_{l}}
\end{array}
$$

$D i f f_{i j}$ は式 (2) 中の右辺第 2 項の全体の拡散項を示

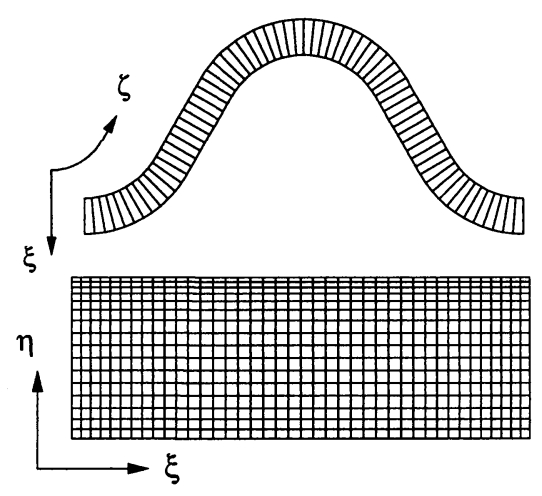

Fig.2 Computational mesh

す.レイノルズ応力輸送方程式をモデル化する際， 問題となる圧力・歪相関項のモデル化に際しては, 四次相関テンソルに付与される制約条件を一部改良 しモデル構築を行った. モデルの導出, 定数決定に ついては別報13)にて詳述した。

さらに乱流エネルギー, 乱流散逸に関しては以下 のモデル化された式を用いた. 各定数はそれぞれ $\sigma_{k}=1.0, \sigma_{\epsilon}=1.3, c_{\epsilon 1}=1.44, c_{\epsilon 2}=1.92, c_{\mu}=0.09$ で ある。

$$
\begin{aligned}
\frac{D k}{D t}=P_{k}+\frac{\partial}{\partial X_{l}}\left[\left(\nu+\frac{\nu_{t}}{\sigma_{k}}\right) \frac{\partial k}{\partial X_{l}}\right]-\epsilon & \begin{aligned}
\frac{D \epsilon}{D t}=c_{\epsilon 1} \frac{\epsilon}{k} P_{k}+\frac{\partial}{\partial X_{l}}\left[\left(\nu+\frac{\nu_{t}}{\sigma_{\epsilon}}\right)\right. & \left.\frac{\partial \epsilon}{\partial X_{l}}\right] \\
& -c_{\epsilon 2} \frac{\epsilon^{2}}{k}
\end{aligned}
\end{aligned}
$$

\section{（3）自由水面の境界条件}

開水路乱流を特徴づける自由水面の影響を境界条 件にいかに反映させるかも開水路乱流を正確に予測 する上で重要な要因となる．本解析では以下のよう な手法により境界条件の設定を行った. 自由水面で の乱流散逸は，一般に壁関数として使用される式を 用い計算を行うこととした。ただし乱流散逸值は， 壁関数を使用する場合と同様に, 自由水面に位置す る計算格子点から流路内部に向かって数えて一点目 に相当する計算格子点で与えられた。また, 主流方 向速度, 水平方向速度および乱流エネルギーは自由 水面で勾配零を, 垂直方向速度は零の境界条件を課 した.

また, 自由水面近傍ではその垂直方向乱れ強度が 自由水面に到達する以前に隇衰し, 自由水面下にて 非常に小さな値を取ることが指摘されている ${ }^{14)}$ 。こ の減衰現象を計算に加味する意味より, 垂直方向乱 れを自由水面から, 計算第一点目まで零とし, この 減衰現象を近似することとした。一般に, 壁面近傍 でも, 壁面に垂直方向の乱れ強度は, 壁面に近づ 
くにつれ減衰し, 自由水面の場合と類似の傾向を 示す。この意味から自由水面も一種の仮想壁と考 えられる。こうした境界条件の導出背景は別報15) にて詳しく報告した。また，本解析流れでは曲が りを有するが，こうした曲がり開水路に対する境 界条件の妥当性に関しても別報16)にて詳述した。

\section{（4）境界適合座標}

境界適合座標系による手法は，物理平面上の解析 領域を計算領域へと座標変換し計算平面上で支配方 程式を解く手法である．境界条件の設定が容易な反 面, 支配方程式は複雑となる。支配方程式の計算平 面上への変換は次の数学定理より変換される。

$$
\frac{\partial}{\partial X_{i}}=\frac{\partial \xi}{\partial X_{i}} \frac{\partial}{\partial \xi}+\frac{\partial \eta}{\partial X_{i}} \frac{\partial}{\partial \eta}+\frac{\partial \zeta}{\partial X_{i}} \frac{\partial}{\partial \zeta}
$$

上式中 $\xi, \eta, \zeta$, 変換された計算平面での座標軸 を示す．同時に，物理平面上では格子形状に沿った 座標軸を示している。上式を用いた各方程式の変換 方法, 変換により導出された輸送方程式, 反変速度, 計量テンソルなどは別報にて詳述されている17).

\section{(5) 数値解析}

数值解析に際しては Fig.1 に示す蛇行開水路のう ち, 1 周期長さの蛇行開水路を対象に解析し, 流路流 入部，流出部には周期境界条件を用いた. 圧力以外 の諸物理量に関しては入口，出口部にて同一値を取 るよう設定し，圧力に関しては入口，出口における 圧力勾配值が等しくなるよう設定した．流量条件に 関しては，特別な制約条件を設けることなく解いた。 また，初期条件に関しては，主流方向速度を断面内 平均速度 $U_{b}$ に, 断面方向速度を零とし, 乱流エネル ギー，乱流散逸值は，それぞれ $U_{b}^{2} \times 10^{-5}, k^{3 / 2} /(4 R)$ と小さな値を設定した。

全体の計算格子配置ならびに矩形断面の計算格子 をFig.2に示す. $\xi, \eta, \zeta$ は格子に沿った座標軸を示し ている. 計算格子は現象変化の急な領域に密に配置 し断面内で $\xi \times \eta=41 \times 17$, 流れ方向に 70 設けた.

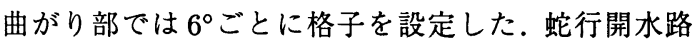
流れでは断面内の圧力変化より水位が変化すること になるが, 計算ではこの水位変化を考慮せず一定水 位として計算を行った。本解析で使用した非等方性 乱流モデルは, 高レイノルズ数型乱流モデルである ことより乱流エネルギー, 乱流散逸方程式の境界条 件には壁関数を用いた。また,レイノルズ応力に関 しては, 輸送方程式を微分型から代数型としたこと により境界条件設定の必要はない.

支配方程式の離散化は有限差分近似により行い, 計算諸量の格子点配置は Regular Grid 法によった。 各支配方程式の対流項差分近似は QUICK(三次精度

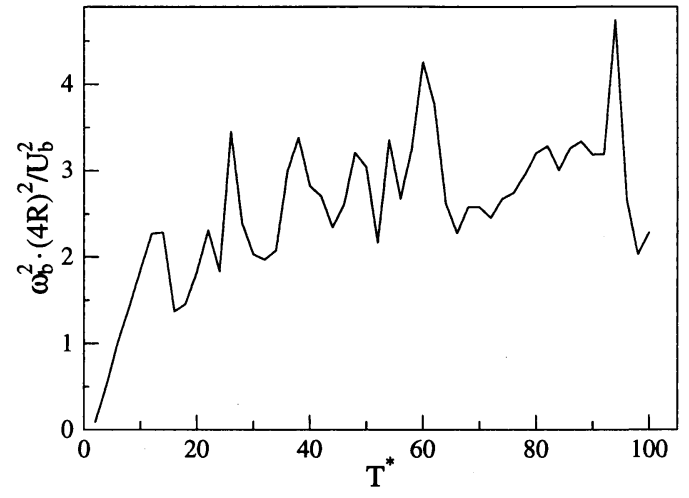

Fig.3 Time variation of square values of streamwise vorticity

の風上差分)を使用した。また非定常項は陽解法と して，次の計算ステップにおける物理量が，既知の 時間ステップの物理量にて表されるよう差分化した。 陽解法の場合，時間刻みは大きく取ることができず Courant 数が常に 1 以下となるよう時間刻みを設定 した. 代数応力モデルの場合, レイノルズ応力輸送 方程式の対流, 拡散項は非定常項も含め式 (3) のよ うにモデル化されるため非定常計算は含まない．圧 力解法に関しては圧力補正量のポアソン方程式を反 復法にて解き, 元の圧力値に加え圧力場, 速度場を 構成する。これを連続の式が満足されるまで繰り返 すことにより圧力場を得た。

\section{4. 結果と考察}

\section{（1）流れの非定常性}

計算結果から，蛇行開水路流れには非定常性が認 められた. Fig.3 は, 開水路入口断面に扔ける主流 方向渦度の 2 乗を断面内で平均化した $\omega_{b}^{2}$ の值を示し た結果である。図中横軸は無次元時間で， $\omega_{b}^{2}$ は $4 \mathrm{R}$ および断面内平均速度にて無次元化した。図に示す ように $\omega_{b}^{2}$ は振動し，流れは非定常性を示す．従って， 実験結果と比較する際には時間平均化の操作を行っ た。計算時の時間間隔は無次元時間で $2.0 \times 10^{-3}$ と した. 10,000 ステップ（物理時間で $12.45 \mathrm{sec}$, 無次 元時間で $T^{*}=20 ）$ の助走計算により流れが発達し たことを確認した後，50,000 ステップ（物理時間で

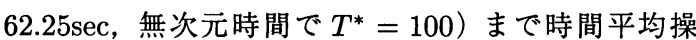
作を行い各平均諸量を求めた。この時, 時間平均化 操作は, 各諸量の変化がなくなるまで行い, 初期条 件の影響，時間ステップの影響を排除した。以下に 実験結果との比較を示すが計算結果は，この平均化 された物理量である。 

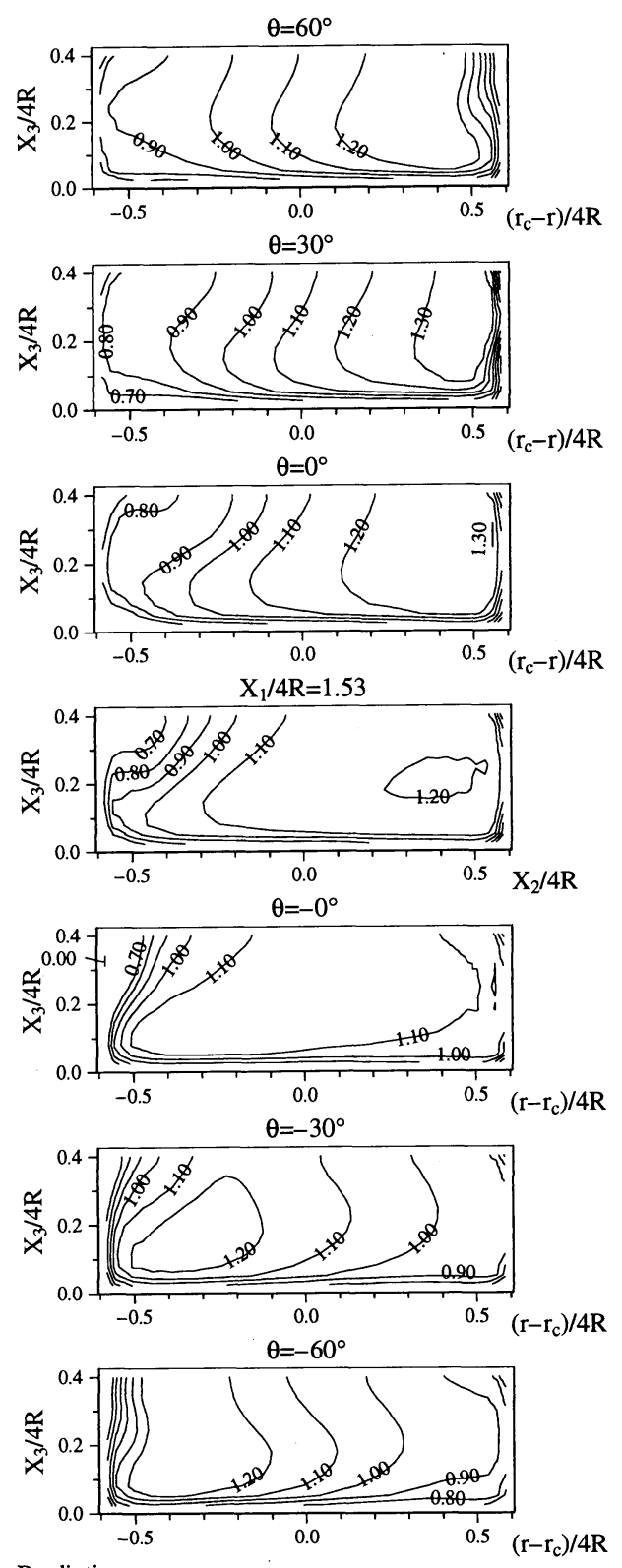

Prediction

$\mathrm{U}_{1} / \mathrm{U}_{\mathrm{b}}$
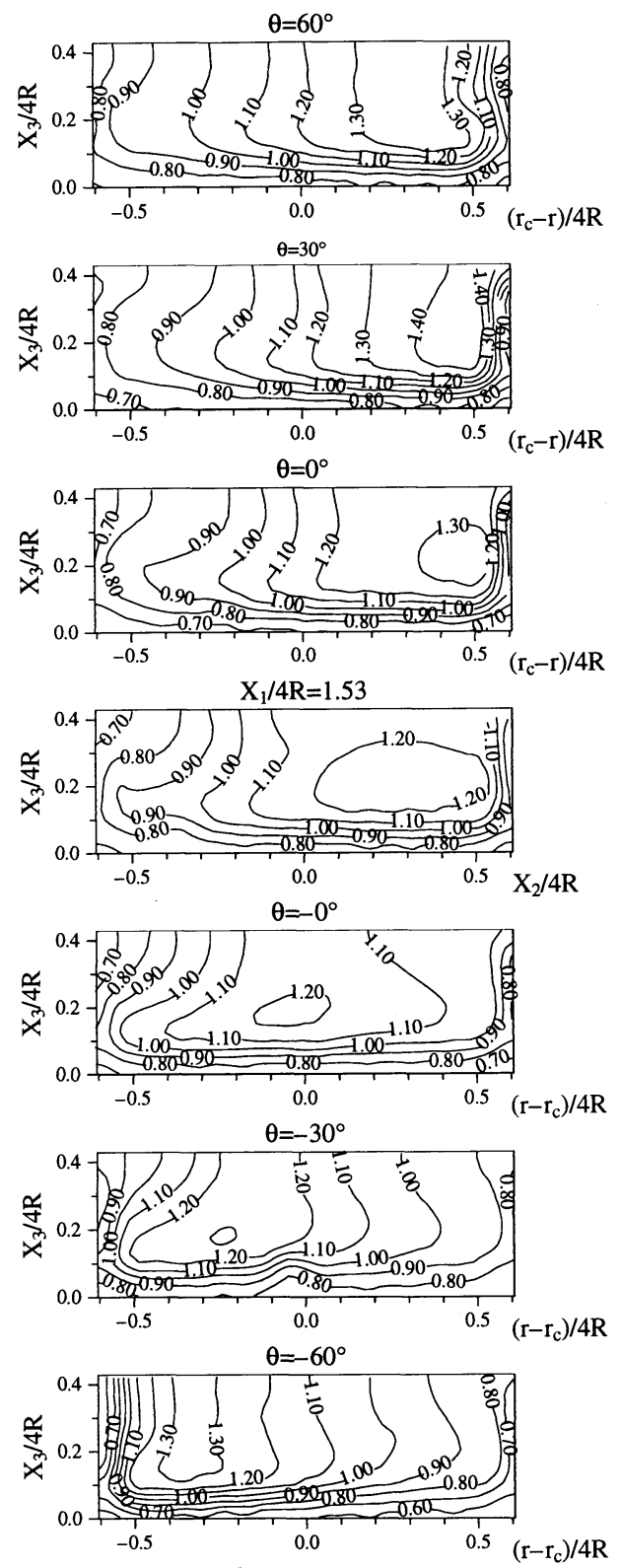

Exp. by Muto et al.

Fig.4 Comparison of streamwise mean-velocity

\section{（2）速度場の比較}

Fig.4 は主流方向速度等值線を比較した結果であ る. 各等值線は主流方向平均速度にて無次元化して いる. $\theta$ が負の場合, 水路断面の左側は内壁を右側 は外壁を示し, 正の場合は左側は外壁を右側は内壁 を示す. 実験結果に見られる特徽的な現象として， 最大主流方向速度の位置は蛇行開水路入口では内壁 側に認められ，流下するにつれ外壁に移行し第二の
蛇行開水路では内壁近傍に最大主流速度が形成され る点を指摘できる。こうした現象は計算結果におい ても良好に再現されている。一般に単一曲がりを有 する開水路では主流方向速度の最大值は外壁側に形 成される18)が, 曲がりが周期的に存在する蛇行開水 路では全く逆の傾向を示しこの種の蛇行開水路に特 徵的な現象と言える。曲がり開水路では内壁から外 壁に向かう遠心力と圧力勾配による外壁から内壁 

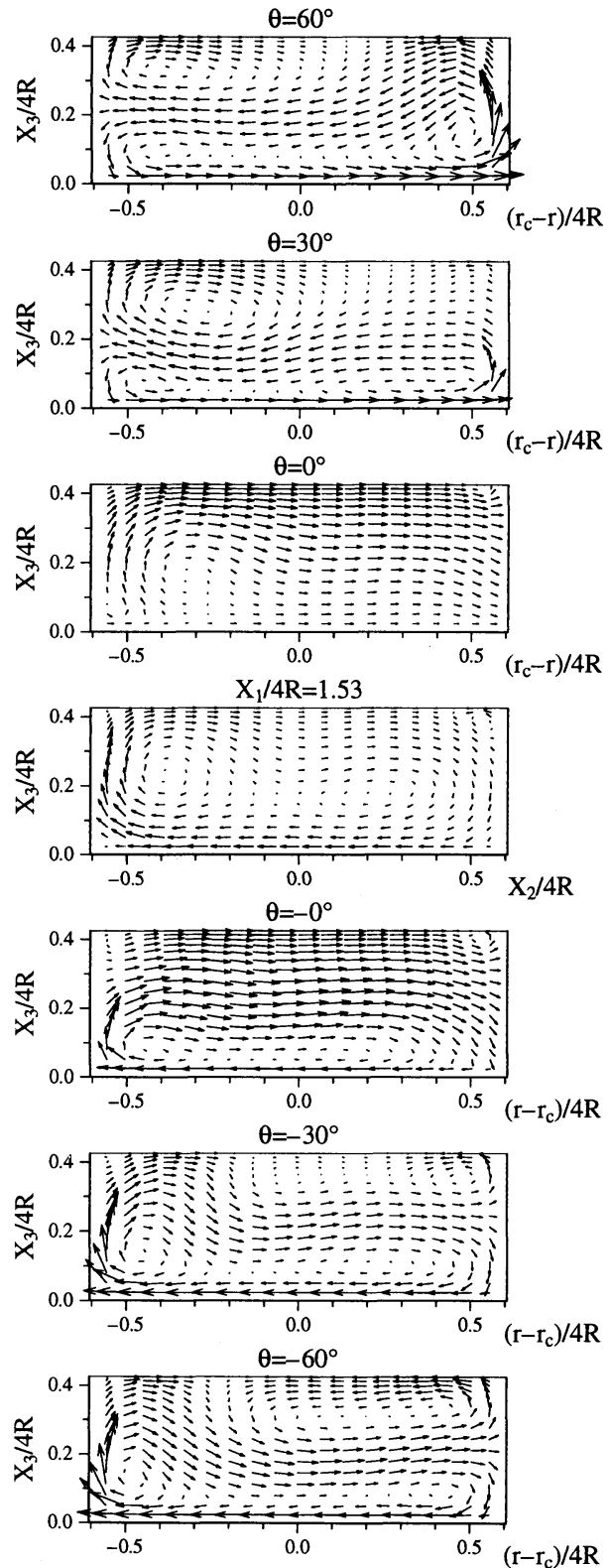

Prediction $\rightarrow 0.1 \mathrm{U}_{\mathrm{b}}$
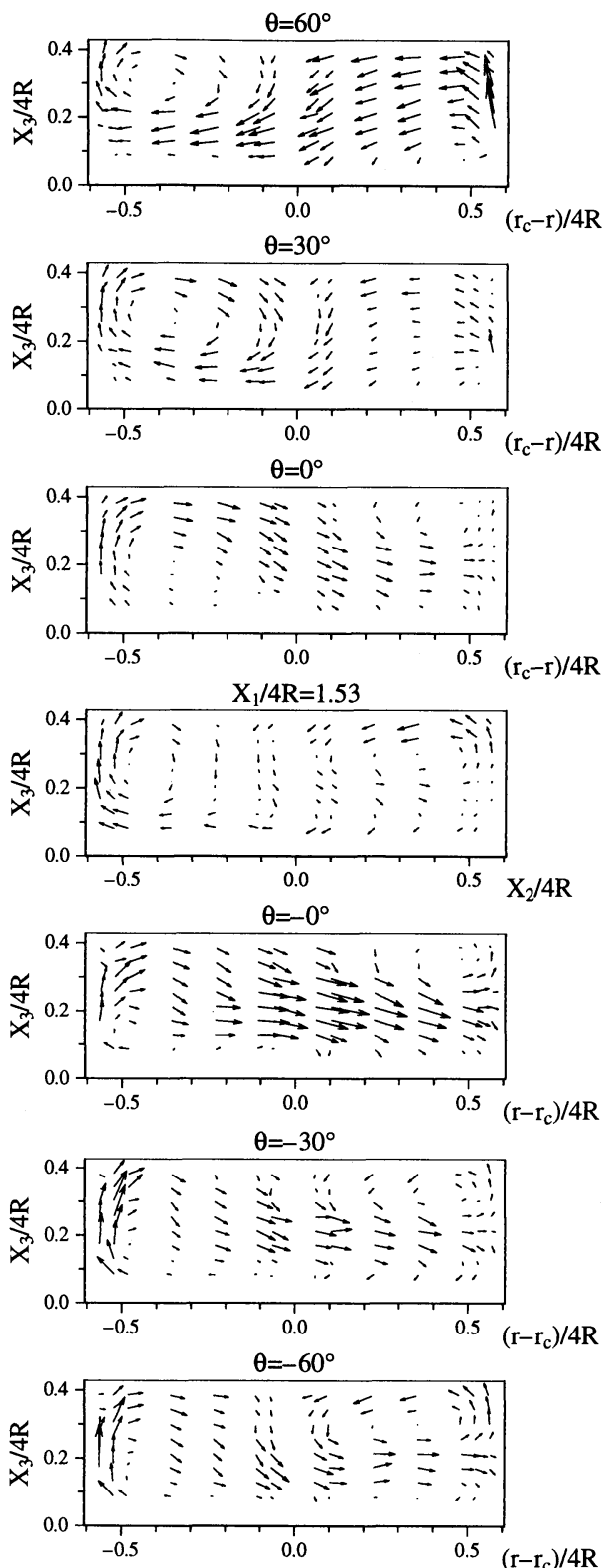

Exp. by Muto et al.

$-0.1 \mathrm{U}_{\mathrm{b}}$

Fig.5 Comparison of secondary flow vectors

に向かう力との大小により流れ場は大きく変化する が, 蛇行開水路の場合外壁に生成される大きな圧力 勾配が遠心力ょり優り, その結果, 主流方向速度の 位置が内壁側に偏ったものと解釈される，外壁側で の大きな圧力勾配の生成は, 蛇行形状に起因したも のと推察され, 自由水面を有しない蛇行閉管路の場 合にも主流方向速度に関し同様な現象が報告されて いる ${ }^{19)}$. 計算結果に特徵的な現象として $\theta=-0^{\circ} に$
おいて零等值ラインがごく僅かな領域であるが内 壁側に存在することを指摘できる，このことは，こ の領域で流れのはく離が形成される可能性が高いこ とを示唆している．また，こうした最大主流方向速 度の位置は二次流れとも深く関わり合う. Fig.5 は この二次流れベクトルを両結果にて比較したもので ある．比較図は上流側からの断面を示している。 た，計算ではベクトル長さの判読が容易となるよ 

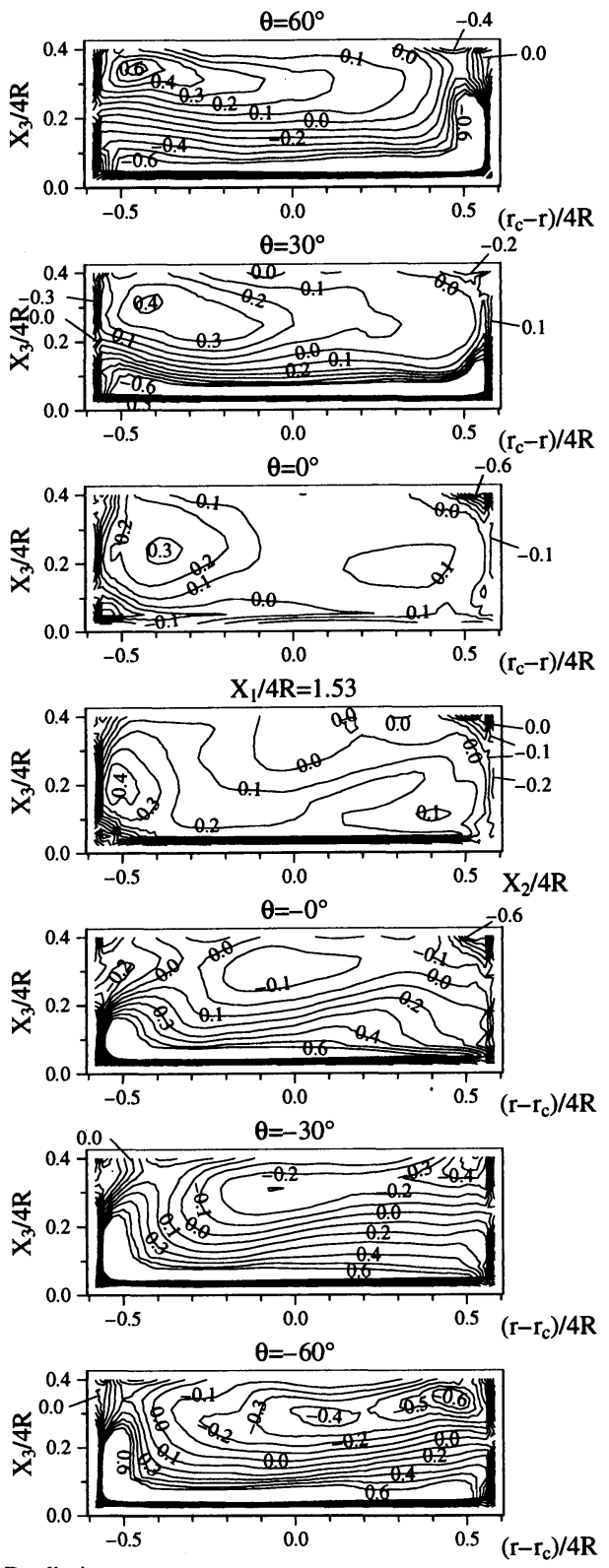

Prediction

$\omega_{\theta} \cdot 4 \mathrm{R} / \mathrm{U}_{\mathrm{b}}$
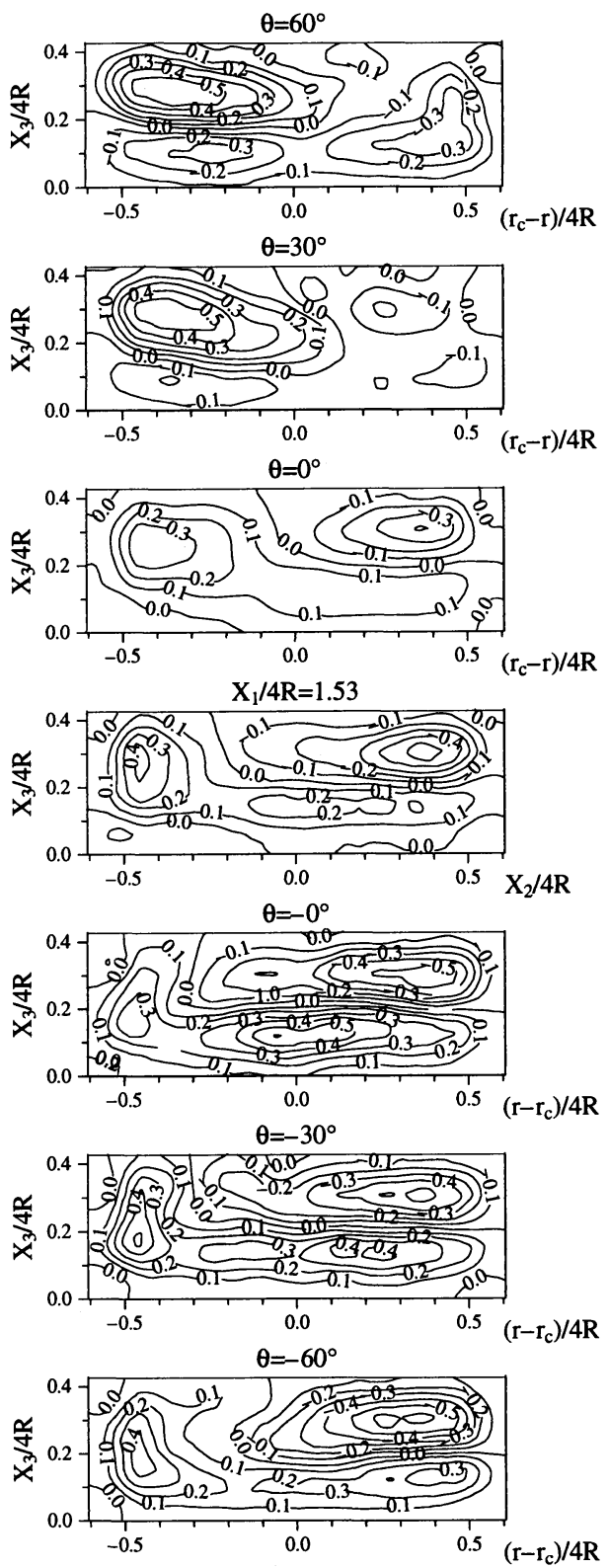

Exp. by Muto et al.

$\omega_{\theta} \cdot 4 R / U_{b}$

Fig.6 Comparison of streamwise vorticity

う, 格子点数を少なくして表示している. 蛇行開水 路入口に相当する $\theta=-60^{\circ}$ の実験結果より自由水面 近傍の $\left(r-r_{c}\right) / 4 R=-0.1$ から 0.5 の範囲にて反時 計周りの渦が認められ，その渦を回り込むように内 壁から外壁に向かう二次流れが河床壁近傍に認めら れる．計算でも同様にこうした二次流れパターンを 再現している．先にこの断面で最大主流方向速度は 内壁に生成されることを示したが, 自由水面近傍の
渦は, 最大主流方向速度の位置を内壁近傍に偏らす 方向に作用している.また蛇行開水路の半周期出口 に相当する $\theta=60^{\circ}$ の二次流れパターンは $\theta=-60^{\circ}$ 断面を下流側から透視したパターンと同一となるこ とが実験, 計算両結果より確かめられる. $\theta=-30^{\circ}$ では遠心力の影響が顕著となり，内壁から外壁に向 かう二次流れが支配的となることが両結果より認め られる.この傾向は第一曲がり開水路の出口に相当 


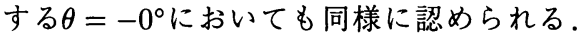

第一曲がりに続く直線水路では，遠心力の作用が 無くなるため二次流れは隇衰することが予測される が，実験および計算でもにこの傾向が認められる. ただし，計算では一つの渦が形成されているのに対 し, 実験では二つの渦が認められる点が異なる。

第二曲がり開水路に流入すると $\theta=0^{\circ}$ では, 曲が り外壁 $\left(\left(r_{c}-r\right) / 4 R=-0.5\right.$ 側 $)$ にて高い圧力が存在 するため外壁から内壁に向かう二次流れが形成され ることになる. 実験では河床壁の $\left(r_{c}-r\right) / 4 R=-0.5$ 近傍にて河床から自由水面に向かう二次流れの上昇 が認められるが, 計算も同様な現象を再現している。 さらに下流の $\theta=30^{\circ}$ に至ると外壁の高い圧力によ る二次流れと, 遠心力による二次流れとが混在し 二次流れは大きく変化する.実験結果から断面中 央より外壁に寄った位置に時計回りの渦の存在が確 認できるが, 計算においてもその渦中心位置は多 少異なるもののその存在を再現している。この渦は $\theta=60^{\circ}$ においても消滅することなく認められる。ま た, $\theta=30^{\circ}$ の計算結果では河床壁に沿うように反 時計回りの渦が認められる. 実験では河床壁近傍で の二次流れの計測結果が明示されていないため直接 比較することはできないが, 計算結果は, 河床壁近 傍の二次流れの存在を示唆している。

次に,こうした二次流れにより形成される渦強度 を比較するため, 各断面における主流方向渦度を算 出した．結果を Fig.6に示す．第一曲がり開水路の 実験には零ラインが外壁側から自由水面へと伸び, 回転の異なる渦対が存在する結果となっている．計 算でも各断面で同様な結果を再現した。また, 実験 では内壁側の自由水面近傍にて同様に零ラインが 認められるが, 計算結果もこうした現象を予測して いる. 定量比較しても, 例えば $\theta=-60^{\circ}$ では最大渦 度の絶対值は実験で 0.5 であるのに対し，計算では 0.6 であり比較的良好に実験值を予測していること が理解できる.直線開水路における両結果を比較す ると第一曲がり開水路と同様な零ライン分布が両 結果で認められる。.また実験では $X_{2} / 4 R=-0.5$ の 壁面領域, $X_{2} / 4 R=0.3$ の自由水面領域に最大渦度 の絶対値で 0.4 の等值ラインが認められる. 計算で は自由水面近傍では差が認められるが, 壁面領域で は実験結果と符合する結果を示している。第二曲が

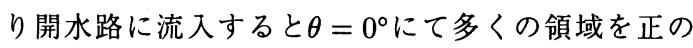
渦度が占めることが両結果に共通して認められる。 $\theta=30^{\circ}$ では, 計算結果は河床壁に沿う反時計まわ りの渦が存在することより, 河床壁近傍に負の等值 線が存在し実験結果とは異なる。しかし， $\theta=60^{\circ}$ に至ると実験結果にも河床壁近傍に負の值を有する 渦度が生成され計算結果と符合する現象を示す。
以上の実験, 計算結果から, 開水路内壁側に比較 的強度の大きな循環流が形成されることが理解で きる。この循環流と先に示した最大主流方向速度 の内壁への移動を考え合わせると，一つの仮説とし て, 蛇行開水路流れの場合, 浸食作用は内壁側壁で 顕著に認められことが予想される．同時にこのこと は, 内壁側の護岸工事が重要であることを示唆して いる。

\section{（3）応力場の比較}

Fig.7に乱流エネルギー分布を比較した結果を示 す. 実験では河床勾配より平均摩擦速度を求め無次 元化しているが, 計算も実験を踏襲し蛇行開水路に おける圧力勾配より算出した平均摩擦速度を用い 無次元化している. $\theta=-60^{\circ}$ での実験結果より開 水路中央部の自由水面近傍にて比較的高い值が, ま た内, 外壁とを比較すると内壁側に高い値が存在す る。内壁側で高い值を示すのは最大主流方向速度の 内壁への移行による速度勾配の増加に起因するも のと解釈される．計算は内壁側の高い值は再現する が, 自由水面近傍の比較的高い值の存在は再現しな い. 特に自由水面近傍の比較的高い值は, 実験では 他の断面でも認められるが, 計算はこうした傾向を

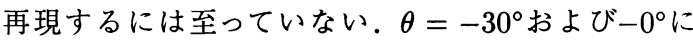
至ると, 開水路中央部の自由水面近傍に認められた 大きな乱流エネルギーは内壁側に移行し， $\theta=-0^{\circ}$ においては大きな值が内壁側の広い範囲を占めるこ とが実験より読みとれる。計算も実験とほほ同様な 挙動を再現するが, 定量的に差が認められる.最大 主流方向速度は内壁から外壁に向かい移動するのに 対し, 乱流エネルギーは逆の傾向を示す。さらに下 流の直線開水路では内壁側 $\left(X_{2} / 4 R=-0.5\right.$ 側 $)$ の自 由水面近傍に高い值が存在する傾向を実験は示す. 第二曲がり開水路に流入すると乱流エネルギーの最 大值は外壁から内壁に向かって移動し， $\theta=30^{\circ}$ では

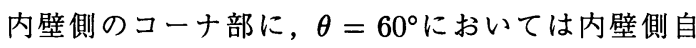
由水面, 河床壁近傍に大きな值が形成されることが 実験より理解できる。計算では $\theta=0^{\circ}$ の外壁にて最 大値を有し実験と異なる分布を示すものの，外壁か ら内壁コーナ部に, コーナ部から自由水面近傍にそ の最大值が移行する現象は再現している。

Fig.8 はせん断応力 $\overline{u_{\theta} u_{r}}$ の等値線を両結果にて 比較した結果を示す.両結果とも平均摩擦速度を用 いて無次元化している. 実験結果の $\theta=-60^{\circ}$ におけ る零ラインに注目すると，そのラインは内壁側に認 められるが下流に流れるにつれてその位置は内壁側 から外壁側に移動して直線開水路においては断面中 央部にまで発達する。第二曲がり開水路に至るとそ の位置は内壁側に移動することが理解できる。また 

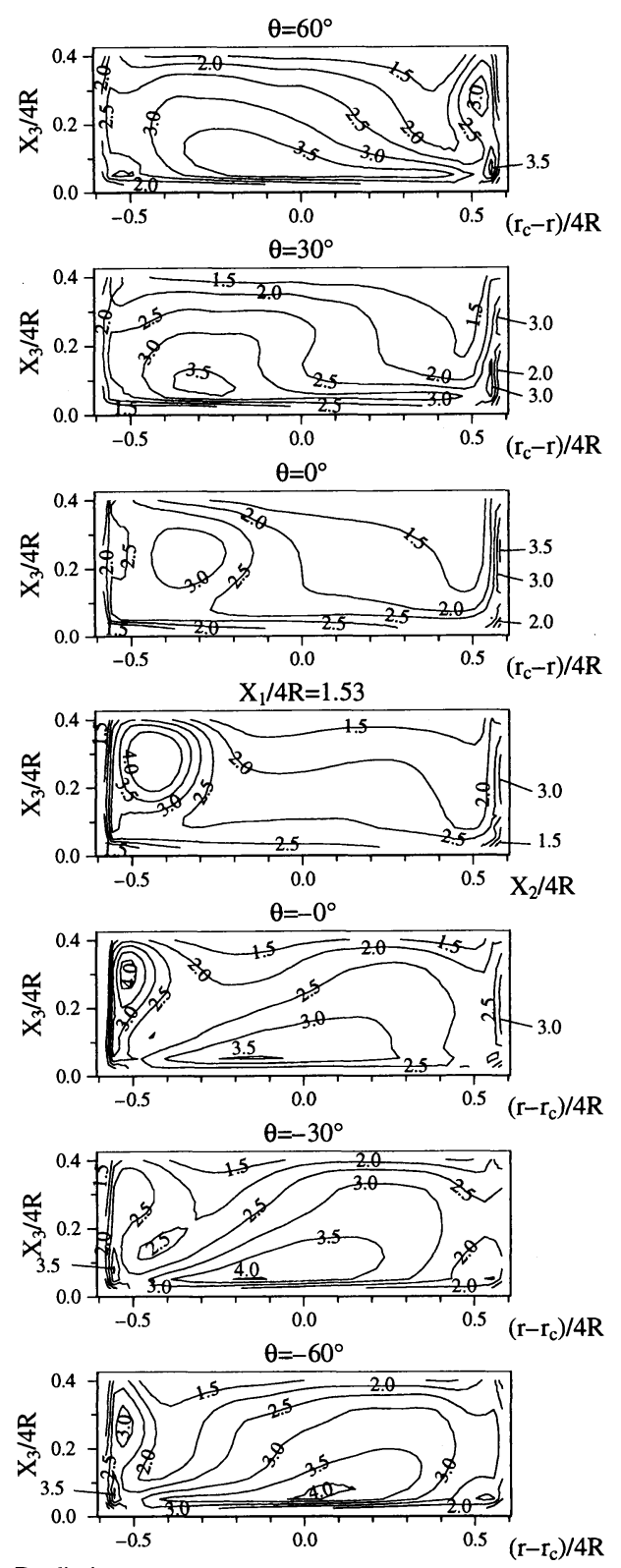

Prediction

$\mathrm{k} / \overline{\mathrm{U}}_{*}^{2}$
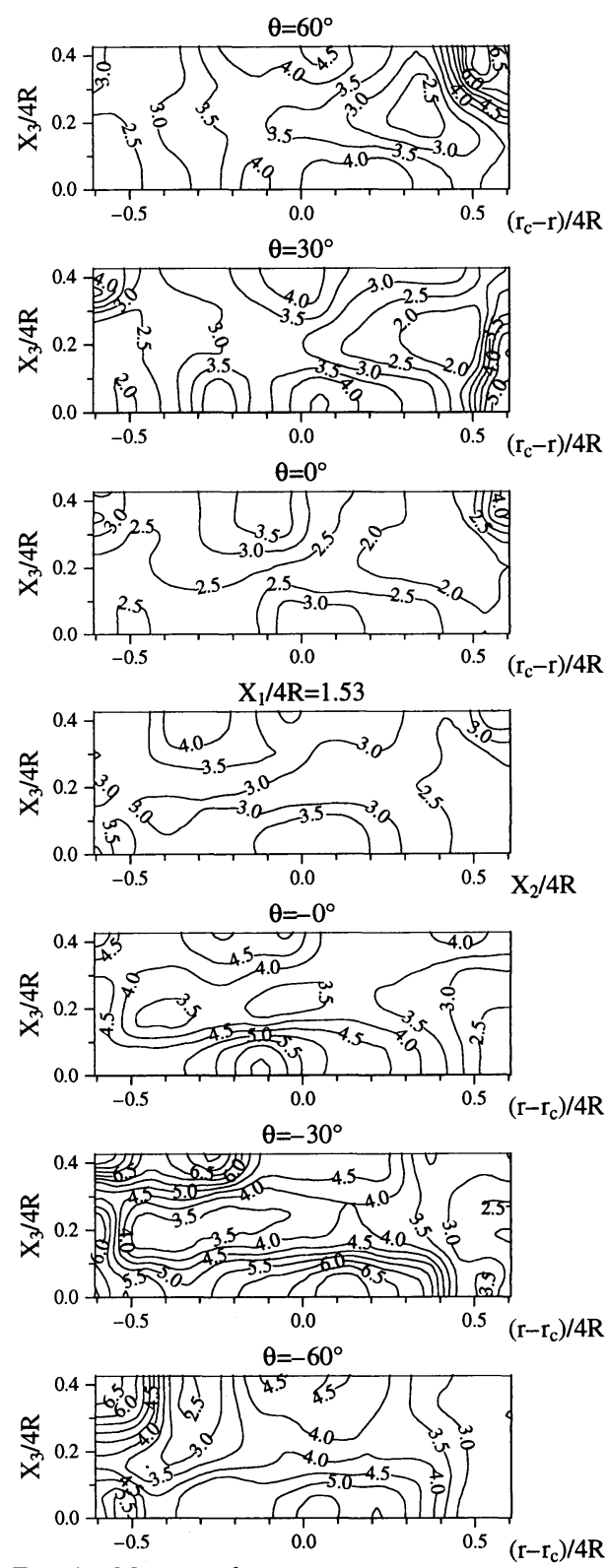

Exp. by Muto et al.

Fig.7 Comparison of turbulent energy

その絶対値の最大に注目すると河床壁あるいは側壁 よりも自由水面で高い值を示している. 一方, 計算 における零ラインに着目すると $\theta=-60^{\circ}$ の内壁側か ら直線開水路を経て $\theta=60^{\circ}$ の内壁側に移動する傾 向は共通し, 零ラインの位置に関しても直線開水路 で実験と異なるものの, 他の断面では比較的良好に 再現している。また, 計算においてその絶対值の最 大は自由水面近傍より河床近傍で認められのに対し
て，実験ではむしろ自由水面近傍に認められる。こ うした自由水面近傍に絶対值の大きな值が存在する 現象を, 本解析手法では再現できない.

Fig.9 ではせん断応力ー $\overline{u_{\theta} u_{z}}$ の等值線を両結果に て比較した結果を示す. 先のせん断応力 $\overline{u_{\theta} u_{r}}$ の零 ラインと比較すると両側壁を結ぶように伸びて異符 号領域を形成する点が異なる。これは主流方向速度 等值線分布から明らかなように，二次流れによりそ 

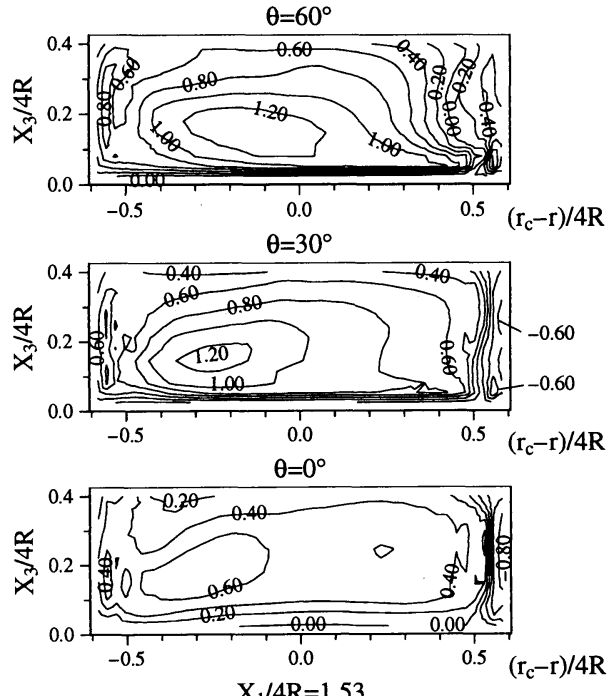

$\mathrm{X}_{1} / 4 \mathrm{R}=1.53$
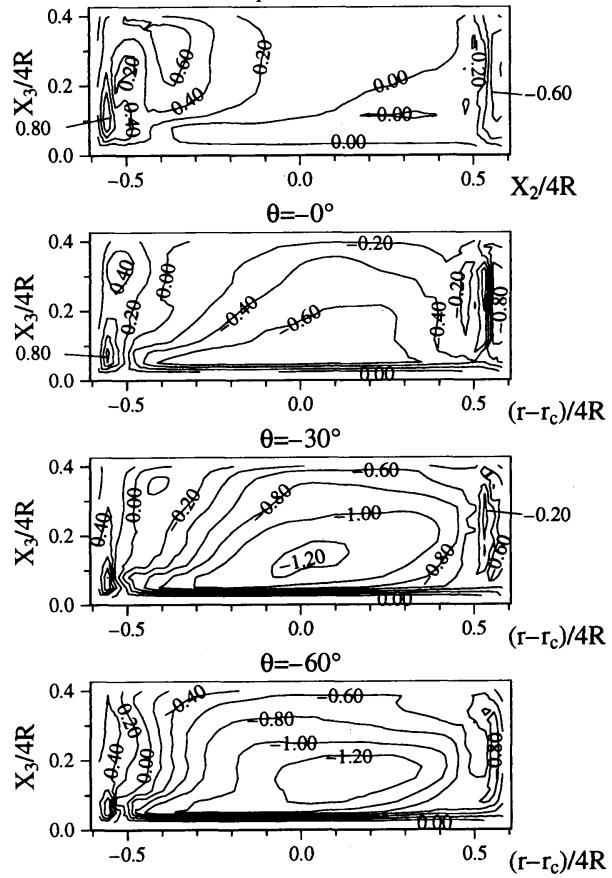

Prediction $-\overline{\mathrm{u}}_{\theta} \mathrm{u}_{\mathrm{r}} / \overline{\mathrm{U}}_{*}^{2}$
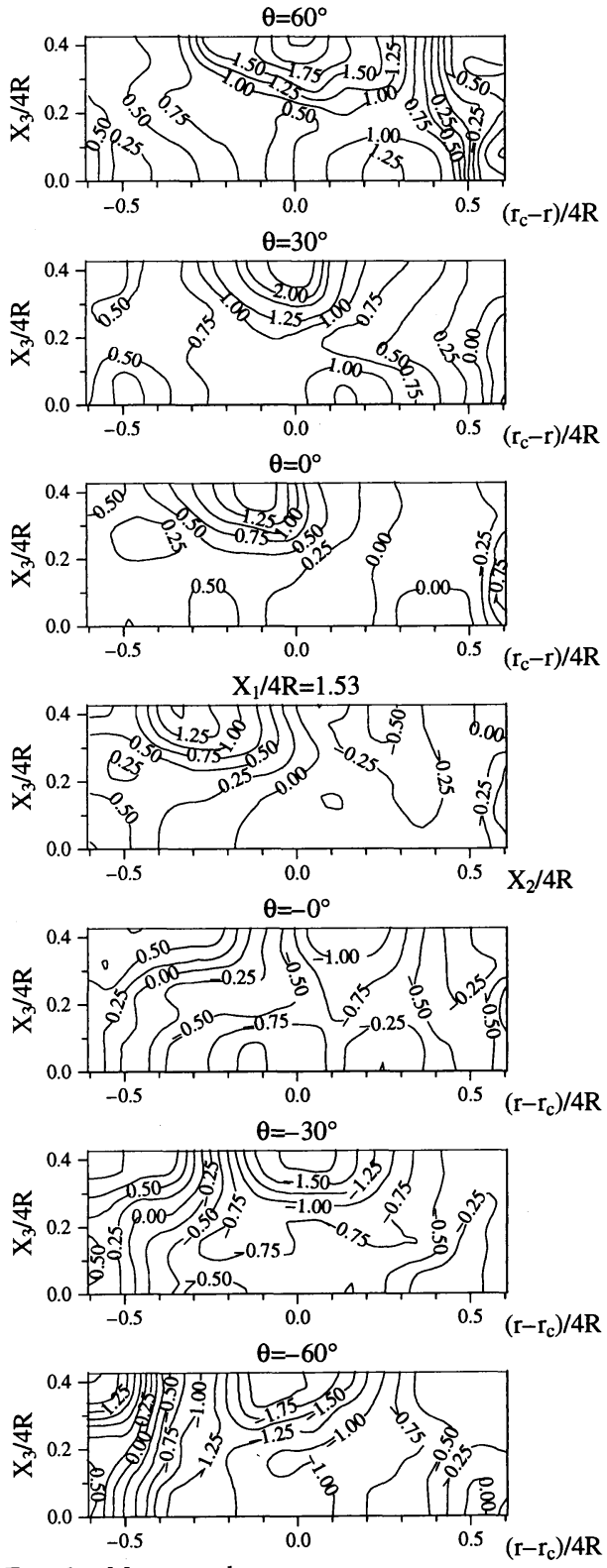

Exp. by Muto et al. $-{\overline{\mathrm{u}_{\theta} \mathrm{u}_{\mathrm{r}}}}{\overline{\mathrm{U}_{*}}}^{2}$

Fig.8 Comparison of shear stress $-\overline{u_{\theta} u_{r}}$

の分布が舌状に変形した結果と解釈される．実験で は両側壁を結ぶ零ラインは流路断面の中央部に存在 する。計算において流路断面中央部以外に自由水面 近くにも認められる。計算で自由水面近傍にも認め られるのは, 前述のように主流方向速度分布が自由 水面近傍の二次流れにより歪みを受けるためと解釈 される，すなわち，せん断応力 $-\overline{u_{\theta} u_{z}}$ が最も簡便な 形として, 渦動粘性係数と速度勾配 $\partial U_{\theta} / \partial X_{3}$ の積
として示されるとすると, せん断応力の符合は, 速 度勾配に左右され, 自由水面近傍では主流方向速度 が, $X_{3}$ 軸の正方向に減少するためと解釈される。 た正値を示す最大值は自由水面近傍より河床壁近傍 に生成されること, 負の領域を形成する領域でも絶 対值の大きな值が零ライン近傍に存在することなど が実験結果から解る．前者の高い值は壁面近傍の乱 流生成によるものであり, 後者の場合は, 二次流 

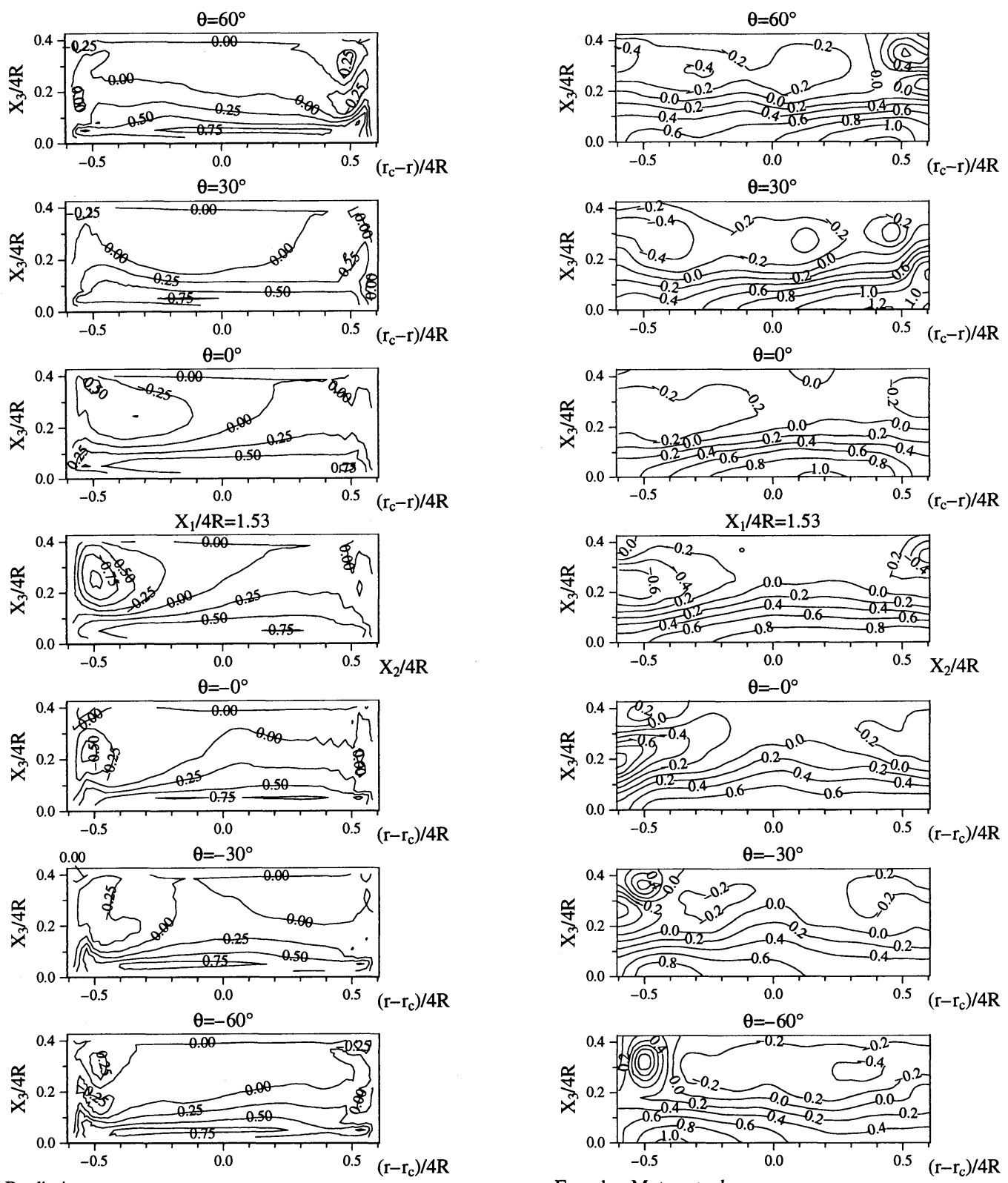

Prediction $-{\overline{\mathrm{u}_{\theta} \mathrm{u}_{\mathrm{z}}}}_{/ \overline{\mathrm{U}}_{*}^{2}}$

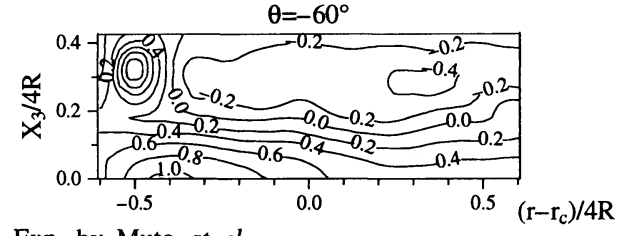

Exp. by Muto at el. $-{\overline{\mathrm{u}_{\theta} \mathrm{u}_{\mathrm{z}}}}_{/ \mathrm{U}_{*}}{ }^{2}$

Fig.9 Comparison of shear stress $-\overline{u_{\theta} u_{z}}$

れの運動量交換により生成された応力と理解され る. 計算も定量的には差はあるもののこうした現象 を再現しており代数応力モデルにおいても蛇行開水 路流れの複雑乱流構造を捕捉できることを示唆して いる.また計算結果のせん断応力の絶対值に注目す ると比較的高い値が第一曲がり開水路内壁から第二 曲がり開水路内壁に移動する現象が認められる.

\section{（4）二次流れの非定常性}

本計算を進めていく際，Fig.3に示したように流 れには非定常性があることが確認された。こうした 非定常性は二次流れにも顕著に認められた. Fig.10 は流路入口断面 $\left(\theta=-60^{\circ}\right)$ における二次流れ分布 を時間経過とともに示した結果である. 図中 $T^{*}$ は 径哚および断面内の主流方向平均速度にて無次元化 した無次元時間である. $T^{*}=58.0$ から 70.0 までの 

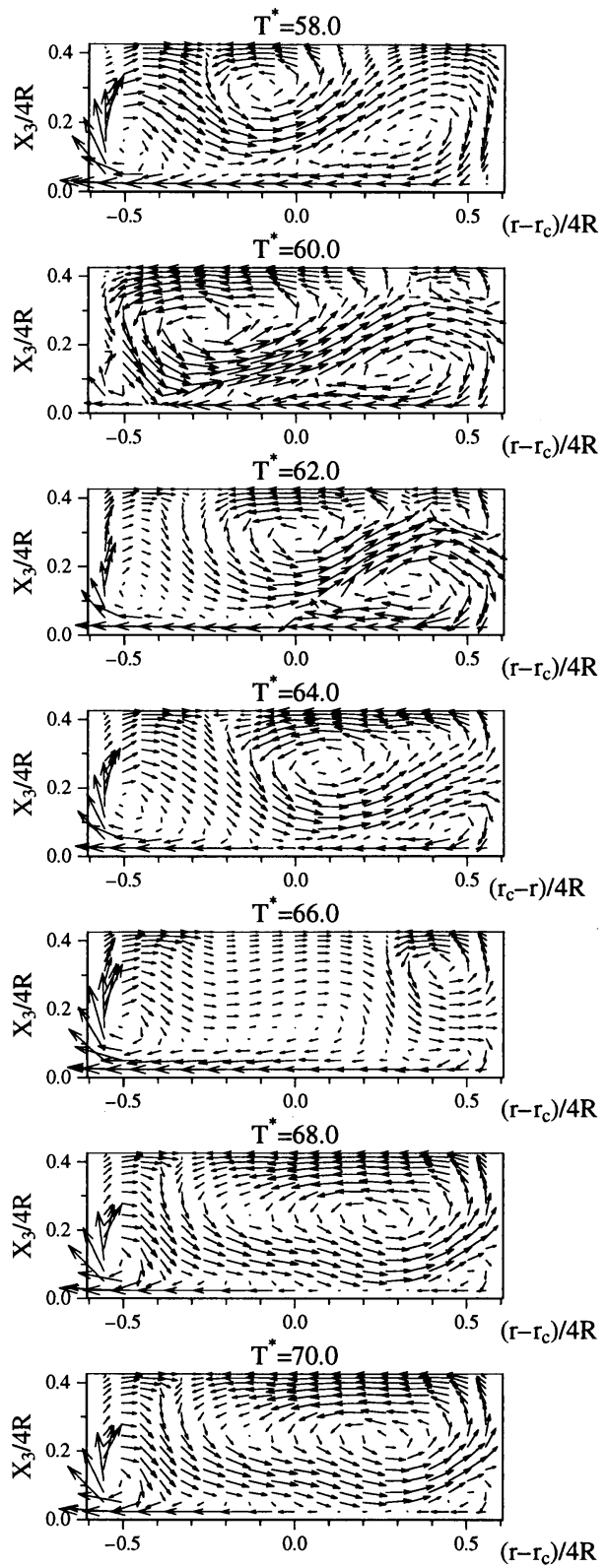

Prediction

$-0.1 \mathrm{U}_{\mathrm{b}}$

Fig.10 Unsteady movement of secondary flow

計算結果を無次元時間間隔 2 (物理時間で $1.24 \mathrm{sec}$ ) ごとに示した。

Fig.5 の $\theta=-60^{\circ} に お け る$ 平均化された二次流れ ベクトルと比較すると二次流れは時間経過と伴に大 きく変化することが理解できる。こうした二次流れ が流路断面内で大きく変化することは，水位も時間 的に変化することを示唆している. 石垣・武藤 ${ }^{20)}$ は 蛇行度 (蛇行水路実長/蛇行波長) が 1.11 と緩やか
に蛇行する複断面, 単断面開水路流れを対象に流れ の水位変動を測定, 水位変動の自己相関係数を算出 することにより単断面, 複断面とも流れに周期性が あることを報告している．本計算では，自由水面変 位が解析できるモデルとはなっていないため, 水位 変動までも予測することはできず水位変動に周期性 があるかについては明言できないが, 流れが非定常 性を示すことについては，共通した結果となった。

こうした二次流れの非定常性が何に起因するの か, どのような機構により生成されるのか興味ある ところである。二次流れ生成に寄与する外力として は遠心力, 圧力勾配による力, 乱流拡散による力が 指摘できる. 安定的な二次流れは，これらの力が定 常的に均衡を保った状態で形成されるものと解釈さ れる。層流流れにおける正方形断面曲がり管路で, 遠心力の不安定により曲がり外壁に付加的な二次流 れが新たに生成されることが報告21)されているが， これは二次流れに作用する力の不均衡により二次流 れは大きく変化することを示唆している．従って， これらの力のうちいずれか一つが, 時間とともに変 化する時, 非定常的な二次流れが生成されるものと 推察される。いずれの力が不安定を誘発する一次要 因となるかについては明らかではない．

\section{5. 結 論}

蛇行開水路流れを対象に代数応力モデル, 境界適 合座標系を用い三次元乱流構造を解析した。解析結 果は実験と比較し差異分析を行うと同時にその流動 場について検討し以下の結論を得た.

(1) 蛇行開水路流れでは最大主流方向速度の位置は 開水路内壁に認められるが本解析手法は定性的にも 定量的にも比較的良好にこの現象を予測した。

(2) 二次流れは第一曲がり開水路で内壁から外壁へ, 第二曲がり開水路では外壁から内壁に向かい形成 されるが計算もそのパターンを比較的良好に予測 した。渦度の定量比較においても計算は実験値を再 現した。

(3) 乱流エネルギーは比較的大きな值が蛇行開水路 の内壁側に存在するが, 本計算においてもこうした 現象を捕捉した。しかし, 自由水面近傍の高い值を 再現するには至らない。

(4) せん断応力分布は定量的には差が認められるが 定性的にはその特徵的な等值線分布を本乱流モデル は再現している．ただし，せん断応力 $-\overline{u_{\theta} u_{r}}$ は絶対 值の比較的大きな值が自由水面近傍に存在するが, この値を再現するには至らない．

(5) 本解析で対象とした蛇行開水路流れの解析結果 は，実験同様，非定常性流れを示した。同時に，二 
次流れも非定常的な流動パターンを示すことを明 らかにした。

(6) 本解析手法は, 蛇行開水路流れの特徵的現象を 比較的良好に再現しこうした複雑乱流場においても 有効であることを示した。しかし，自由水面近傍の 乱流エネルギー, せん断応力の比較的高い値を再現 するには至らない。

謝辞：本研究を行うに際し Loughborough 大学, 塩 野耕二教授からは有益なご助言を賜った。また，京 都大学防災研究所, 武藤裕則博士からは実験デー夕 の供与を賜った。ここに記して謝意を表する。

最後に本研究遂行に際し文部省科学研究補助金 （基盤研究 (C),No.10650198)，の援助を得たことを付 記し謝意を表する。

\section{参考文献}

1) Tominaga,A. and Nezu,I.:Turbulent structure in compound open-channel flows, J. Hydraulic Eng., ASCE, Vol.117, No.1,pp.21-41,1991.

2) Naot,D.,Nezu,I. and Nakagawa,H.:Hydrodynamic behaviour of compound rectangular open channel, J. Hydraulic Eng., ASCE, Vol.119, No.3,pp.390-408,1993.

3) Toebes, G.H. and Sooky,A.A.:Hydraulics of meandering rivers with flood plains,Proc.ASCE, Vol.93, No.WW2, pp.213-236,1967.

4) Kiely,G.K.:Overbank flow in meandering compound channels, the important mechanisms, Int.Conf.on River Flood Hydraulics, Wallingford, pp.207-201,1990.

5) 玉井信行, 池内幸司, 山崎晶:連続わん曲水路に打け る流れの実験的研究, 土木学会論文集, No.331,pp.8394,1983 .

6) 池田駿介, 田中昌宏, 千代田将明:空気蛇行流の乱流特 性に関する研究, 土木学会論文集, No.351/II-2,pp.7786,1984 .

7) 渡辺勝利, 大成博文, 斉藤隆:低レイノルズ数における 蛇行水路乱流の組織構造, 土木学会論文集, No.467/II23,pp.9-18,1993.
8) Shiono,K. and Muto,Y.:Secondary flow structure for inbank and overbank flows in trapezoidal meandering compound channel,Proc. 3rd Symp. on Refined Flow Modelling and Turbulence Measurements,1993.

9) 武藤裕則, 塩野耕二, 今本博健, 石垣泰輔:複断面蛇行開 水路流れの水理特性について (1), 京都大学防災研究 所年報, 第 38 号 B-2,pp.561-580,1995.

10）池内幸司,玉井信行:蛇行水路における水深平均流れ場 の遷移特性, 土木学会論文集, No.334,pp.89-101,1983.

11) 池谷毅,玉井信行:平坦固定床蛇行水路における 3 次元 流況の解析, 土木学会論文集, No.342,pp.107-113,1984.

12) Rodi, W.:A new algebraic relation for calculating the Reynolds stresses, Z.Angew.Math.Mech.56,pp.T219$\mathrm{T} 221,1976$.

13) 杉山均, 秋山光庸, 山中和典, 平田賢:縦筋を伴う三次元 河川流路の乱流構造解析, 土木学会論文集,479/II-25, pp.81-90,1993.

14) Nakagawa,H., Nezu,I. and Ueda,H.:Turbulence of open channel flow over smooth and rough beds,Proc.of Japan Soci. Civil Engrs.,241,pp.155-168,1975.

15) 杉山均, 秋山光庸, 松原珠:複断面開水路内の乱流構造 解析と縦渦生成に関する研究, 土木学会論文集, $515 / \mathrm{II}-$ 31, pp.55-65,1995.

16) 杉山均, 秋山光庸, 亀澤正之:曲がり開水路乱流の構造 解析と二次流れ遷移に関する研究, 土木学会論文集揭 載予定

17）杉山均, 秋山光庸, 平田 賢, 上野智志:三次元非等方性 乱流場における熱流動解析, 機械学会論文集 (B 編), 57 539,pp.2269-2276,1991.

18) 今本博健, 石垣泰輔, 藤沢寛:複断面湾曲開水路流れの 水理特性について (1), 京都大学防災研究所年報, 第 25 号 B-2,pp.529-543,1982.

19) 須藤浩三, 高見敏弘, 藤田昭文:繰り返しベンド内の乱 流, ターボ機械, 第 21 巻第 6 号,pp.329-335,1992.

20) 石垣泰輔, 武藤裕則:緩やかに蛇行する低水路を持つ 複断面開水路流れに関する実験的検討, 水工学論文 集, 第 42 巻,pp.943-948,1998.

21) Mees,P.A.J., Nandakumar,K. and Masliyah,J.H.:Instability and transition of flow in a curved square duct: the development of two pairs of Dean vortices, J. Fluid Mech.,Vol.314,pp.227-246,1996

(1998.11.4 受付)

\title{
NUMERICAL STUDY OF TURBULENT STRUCTURE IN RECTANGULAR MEANDERING CHANNEL FLOW
}

\author{
Hitoshi SUGIYAMA,Mitsunobu AKIYAMA and Ryosuke SATO
}

\begin{abstract}
Numerical study of turbulent flow developing in a meandering open-channel with rectangular cross sections has been carried out by using an algebraic stress model. The flow of interest to the study is one periodic meandering channel of five ones. In the calculation, govering equations are transformed from the physical plane to the calculation plane by using boundary-fitted coordinate system. The calculated results show that unsteady flow is observed for this meandering channel. Therefore, time-averaged numerical results are compared with the experimental data measured by Muto et al. It was found that the present numerical simulation could predict well the characteristic features of streamwise velocity, i.e. the maximum streamwise velocity generated inner bank at bend apex and the location of the maximum velocity moved to the other side bank along the meandering channel, which is different from those of curved open-channel flow. Adding to this, the distributions of secondary flow and Reynolds stresses are reproduced by the present method. The calculated results also suggest that meandering channel flow is featured by unsteady movement of the secondary flow pattern.
\end{abstract}

